\title{
Video, en læringsressource i universitetsundervisningen
}

\author{
Et kommunikationsteoretisk blik på videoformater i \\ universitetsundervisningen
}

Helle Mathiasen, Københavns Universitet

\begin{abstract}
Brugen af video i undervisningen har gennem de seneste dekader til stadighed fyldt mere i billedet af anvendte læringsressourcer på universiteterne. Med et kort tilbageblik på de seneste godt ti års brug af videoformater dykkes der ned i anvendelser af videoformater $\mathrm{i}$ undervisningen med udgangspunkt i en tematisk tilgang. Artiklen ser videoformater som en læringsressource, og dermed som en parameter $\mathrm{i}$ en didaktisk rammesætning af undervisningens forberedelse, gennemførelse og efterbehandling. Med et kommunikationsteoretisk perspektiv diskuteres, hvad der er i spil, når videoformater indgår som en læringsressource i undervisningen, herunder muligheder og faldgruber. Artiklen afsluttes med en opfordring til fortsat didaktisk udvikling, hvor videoformater, set som læringsressourcer, udvikles med fokus på stadig flere studenterinvolverende aktiviteter og med øje for aktiviteter, hvor studerende, undervisere, forskere og professionelle videoproducenter er aktører.
\end{abstract}

\section{Engelsk abstract}

The use of video in the teaching has, over the past decades increasingly filled the image of applied learning resources at the universities. With a brief look back on the past ten years using of video formats in the teaching, the paper focuses on a thematic approach to the use of video formats. The paper observes video formats as a learning resource, and thus as a parameter in a didactic framework setting of teaching preparation, implementation, and finishing. With a systems theoretical inspired concept of communication perspective, the paper poses the question: What is in play when video formats are included as a learning resource is actualised in the teaching environment? The article call for continued didactic development, with focus on video formats, seen as learning resources and with a focus on more and more student involvement activities, including collaboration between students, teachers, researchers and professional video producers. 


\section{Indledning}

Artikel indledes med tematiske nedslag i primært de seneste ti års artikler omhandlende videobrug i universitetsundervisning. Efter en kort præsentation af videobegrebet inddrages artikler omhandlende videoanvendelser i universitetsundervisningen publiceret i tidsskriftet Læring og Medier i anledningen af tidskriftets 10-årsjubilæum. Der trækkes tråde tilbage til Thomas Edisons teknologioptimistiske tilgang til "the motion pictures" (Cuban, 1986) og med nedslag i national og international litteratur fremdrages didaktiske refleksioner, der kobler videoformater og videobrug til den konkrete undervisningskontekst. Den didaktiske rammesætning, inkluderende valg af undervisningsorganiseringer og -former, læringsressourcer, undervisningsaktiviteter, test m.m., er omdrejningspunktet for artiklens efterfølgende tematiske nedslag.

Artiklens har et kommunikationsteoretisk blik på videoformater og på præmisser for videobrugt, iagttaget som en læringsressource i konkrete undervisningskontekster. Det valgte kommunikationsbegreb giver en udsagnskraft i forhold til at diskutere, hvad der er i spil - og hvad der peger på muligheder og faldgruber, når fokus er på kommunikationsmuligheder og -betingelser $\mathrm{i}$ undervisningsrelaterede sammenhænge. Med afsnittet om video som formidlings- og undervisningsformat præsenteres den teoretiske optik, som er det gennemgående perspektiv på konkrete anvendelser af videoformater i de valgte undervisningskontekster. Med udgangspunkt i det præsenterede kommunikationsbegreb tematiserer afsnittet om videoformater set som en læringsressource udvalgte konkrete videoformater, hvor videoformater ses i forhold til didaktiske initierede tidsdimensioner og afsluttes med en et konkret eksempel på et videoformat brugt til feedbackaktiviteter.

Artiklen afrundes med konkluderende perspektiver på udvikling af undervisningsformer og organiseringer, hvor videoformater, set som læringsressourcer, fortsat produktudvikles og hvor såvel studerende, undervisere, forskere som professionelle videoproducenter er aktører i denne udviklingsproces.

\section{Videoformater gennem tiden}

Video bliver brugt i stadig større omfang på universiteterne i Danmark (fx Bregnhøj et al., 2016; FogPetersen \& Arnfred, 2015; Hansen \& Jensen, 2016; Neutzsky-Wulff, 2009; se også LOM nr. 2, Godsk \& Dalsgaard, 2009). Set fra et globalt perspektiv kan samme udvikling af videoanvendelser ses i universitetsverden (fx Reutemann \& Rubner, 2018; Sims, 2008; Wang et al., 2007).

Videoformatet er karakteriseret ved at inkludere en flerhed af kommunikationsmodi. Det vil sige, at videoformatet ofte aktualiserer både tekst, billede, lyd, animation og film ("levende billeder"). Det handler om en flerhed af kommunikationsmodi, som på samme tid kan præsentere et tema med flere kommunikative virkemidler. I en undervisningskontekst vil video i denne artikel betragtes som en mulig læringsressource, der via sin flerhed af kommunikationsmodi kan understøtte læring og dermed videnkonstruktion. Videoformatet betragtes i artiklen som et udbredelsesmedie (Luhmann, 2000) med reference til en systemteoretisk tilgang til mediebegrebet. En udfoldelse af begrebet kan i denne sammenhæng være en optik, der kan give et billede af kompleksiteten. Således vil artiklen betragte videoformater som "et mangefacetteret multifunktionelt udbredelsesmedie" (Mathiasen, 2002, s. 92). Videoformatet kan ses i mange optikker, blandt andet i forbindelse med produktion, virtuelle labs, samarbejdsaktiviteter, individuelle læringsprocesser/adaptive programmer, faglig formidling, undervisningsorganisering, "læringsplatforme" og datagenerering (til fx learning analytics).

En tidligere ofte brugt betegnelse, multimedie (Fibiger et al., 2001), fortæller om en læringsressource, der tilbyder en variation af kommunikative modi og dermed en flerhed af kommunikative 
tilkoblingsmuligheder. Man kan måske tillægge Edison et vist disruptionpotentiale med følgende citat fra 1922:

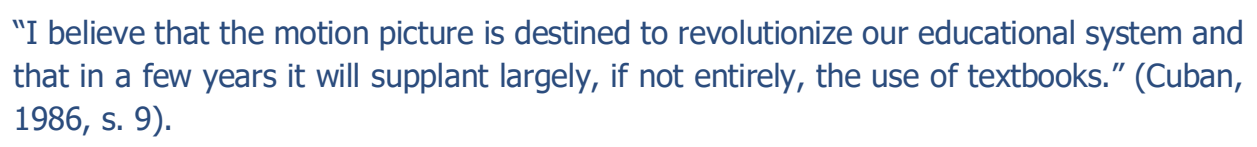

Edison har et ikke ukendt fokus på effektivitet, hvilket kommer til udtryk i hans "believe", som handler om, at textbooks kun kan give $2 \%$ "efficiency", mens "the motion pictures" skulle kunne give op til 100\% "efficiency" (Cuban, 1986).

Edisons begejstring for de nye teknologiske landvindinger er ikke enestående. Der har været flere bølger, hvor aktørerne inden for såvel det politiske system som uddannelsessystemet har tilskrevet "ny teknologi” en afgørende rolle som den enkeltfaktor, der kan overkomme de til enhver tid pædagogiske og didaktiske udfordringer (Cuban, 2002). Forventningerne til "ny teknologi” har således været mere eller mindre eksplicitte i forhold til øget motivation hos studerende og større læringsudbytte. Forskere har gennem en årrække problematiseret disse forventninger, og flere har samtidig via deres forskning fundet, at der ikke er en simpel kausalitet beroende på, at brug af digitale teknologier resulterer i større læringsudbytte (fx Elstad, 2016). Feltet er mere komplekst end som så, hvilket en række forskere med en bred variation af tematiske optikker har fundet gennem tiden (fx Langset et al., 2018; Laurillard, 2012; Mathiasen, 2004; Mor, 2014,).

Et tema, som denne artikel blot vil nævne, er forventningerne til videoproduktioners ressourcemæssige effektiviseringspotentiale. Aktører bl.a. i det politiske system og uddannelsessystemet har gennem tiden set film/videoproduktioner som en mulighed for at kunne reducere omfanget af underviserressourceforbrug og anlægsomkostninger ud fra en logik, der handlede om at film/videomedierede forelæsninger kunne tilgås af studerende uden krav om tilstedeværelse på universitetscampus (Cuban, 2002). De seneste år har der løbende været en vis bekymring og direkte modstand hos specielt undervisere, hvad angår den kategori af videoformater, der kan betegnes som "videooptagelse og -streamning af undervisning" (Rattleff \& Holm, 2009). Denne tendens i forhold til at optage forelæsninger kan stadig findes blandt universitetsundervisere. Der findes p.t. ikke større empiriske forskningsprojekter inden for dansk universitetsforskning, der kan udfolde og tilbyde resultater med fokus på en effektivitetstænkning og omkostningsreduktion ved brug af videoformater i undervisningen. Udfordringer med specielt en effektivisering som fokus, er et diskussionstema i sig selv og vigtig at få undersøgt nærmere.

Teknologianvendelse og tilgange til teknologiers rationale er blevet udfordret gennem årene af pædagogiske og didaktiske erfaringer fra praksis og af forskning i praksis som genstandsfelt. I dag står af anvendelse af digitale teknologier på et forskningsfunderet fundament og med kvalificerede perspektiver på pædagogiske og didaktiske tilgange til læringsressourcer som videoformater. Video, også benævnt som "podcast”, er løbende blevet produktudviklet og med et stadigt større fokus på de studerendes mulighed for at lære sig det, der er intenderet i forbindelse med brug af den konkrete læringsressource (Heilesen, 2009). Samtidig viser den didaktiske praksis og forskning, at undervisningsmiljøets betydning i stadig højere grad er i fokus (Buus et al., 2018; Danielsen et al., 1997; Danielsen et al., 2002; Fibiger et al., 2001; Godsk \& Hansen, 2016; Hansen et al., 1995; Lauridsen et al., 2016; Løkkegaard \& Ryberg, 2013; Mathiasen, 2010). I dag udbydes der i universitetsregi en bred vifte af såkaldte interaktive videoformater, der i et didaktisk perspektiv er tænkt som læringsressourcer (se fx: https://cobl.ku.dk/news/2017/laboratoriesikkerhed/). Læringsressourcer i den forstand at de skal kunne facilitere de studerendes proces frem mod at lære det, der er intentionen med undervisningen, og det ud fra den enkelte studerendes præferencer og tilgange til undervisning og egen læring.

Med Open Educational Resources (OER), (fx Caswell et al., 2008; McKerlich et al., 2013) og Massive Open Online Courses (MOOC) (Baturay, 2015; Zawacki-Richter et al., 2018) blev mængden af 
tilgængelige læringsressourcer af en anden dimension både med hensyn til access og mere eller mindre rammesatte undervisningskontekster og -aktiviteter. Hertil kan tilføjes YouTube-videoer, som bl.a. tilbyder et stort repertoire af videoer producerede af såvel studerende som undervisere (Mathiasen \& Schrum, 2008). Via universiteternes platforme deles ikke kun videoer, men også undervisningsforløb inklusiv forslag til studenteraktiverende opgaver/øvelser og bl.a. selvtests (se bl.a. Nordic University Health Hub, 2019), ligesom flere universiteter har kontrakter med medieplatformsudbydere, der tilbyder en bred vifte af tilbud som eksempelvis Kaltura.

Et ofte brugt format er det såkaldte "talking head"-videoformat, som tilbyder filmede forelæsninger med bl.a. en fortløbende slidepræsentation i den ene skærmside. Fra de første "talking head"forelæsningsvideoer har produktudvikling, hvor tilkobling af fortløbende præsentationsværktøjer samt mulighed for løbende skriftlig synkron kommentering fra studerende, været med til at bringe begrebet interaktive videoer på banen. Test $\mathrm{i}$ form af såvel formativ og summativ evaluering koblet til videoformater er ligeledes blevet en gængs måde for underviserne at få informationer om de studerende via digital voting systems, som Kahoot, Socrative og clickers (Mathiasen, 2015). Yderligere er brug af videoformaterne sat $i$ en didaktisk ramme som eksempelvis i forbindelse med organiseringen af undervisning som "flipped classroom" (se fx https://cobl.ku.dk/news/2017/nyt-kursusforloeb-faarveterinaerstuderende-paa-1.-aar-til-at-braende-for-faget/). Men også nye videoformater som blandt andet instruktionsvideoer, demonstrationsvideoer og "feltvideoer" er blevet aktualiseret gennem de seneste mange år (Huber \& Werner, 2016; Mathiasen, 2010).

\section{Video som formidlings- og undervisningsformat — en kommunikationsoptik}

Det anvendte kommunikationsbegreb er inspireret af sociologen Niklas Luhmann, og valgt på grund af dets udsagnskraft, når videoformater og deres anvendelsespotentiale er i fokus og skal diskuteres (Mathiasen, 2008). En kommunikationsenhed defineres som en syntese af tre selektioner, hvor de to selektioner -1) valg af information og 2) meddelelsesform - foretages af "den meddelende", mens den tredje selektion, 3) valg af forståelse - foretages af "adressat". Præmissen er, at der mindst er to personer "til stede" for at der kan dannes en syntese, og dermed én kommunikationsenhed. Kommunikation konstituerer et socialt system, fx kan campusbaseret eller netmedieret undervisning på et hold studerende udgøre et socialt system. Når en kommunikationsenhed (syntesen af de tre selektioner), hvor eksempelvis underviser vælger 1) information og 2) meddelelsesform rettet mod en eller flere studerende (adressater), som 3) vælger forståelse af den meddelte information, efterfølges af ny kommunikationsenhed, kan det enten være et udtryk for begrebet formidling eller begrebet interaktion.

Når en studerende i et forskningsinterview fortæller, at selvom han har hørt den lærerproducerede podcast 20 gange, har han ikke forstået dét, det der bliv formidlet (Mathiasen, 2010), er der med det præsenterede kommunikationsbegreb basis for kritisk at reflektere over det konkrete videoformats mulighed og begrænsning. Den studerendes refleksioner over egen forståelse inviterer til et kommunikativt fokus på, hvad der skal til, for at den studerende kunne hjælpes på vej til den af underviseren intenderede forstålse af den formidlede information. Podcasten i sig selv giver ikke mulighed for at spørge eller teste egen forståelse. Formatet giver heller ikke mulighed for at formidle informationen på anden måde, hverken sprogligt, via simuleringer, animation eller andre kommunikative muligheder. Den studerende kan muligvis have lært sig "det udenad”, hvad der naturligvis også kunne være intentionen med podcasten. 


\section{Formidling, interaktion og undervisning}

Med begrebet formidling er fokus i udgangspunktet på "den meddelendes" valg af fortløbende information og meddelelsesform. Når underviser i en fortløbende kæde af valg af information og meddelelsesform, som det blandt andet er tilfældet i en videomedieret forelæsning, handler det om formidling. Den studerende kan så vælge at rette sin opmærksomhed med den videomedierede forelæsning og prøve at "hænge på" ved fortløbende at prøve at forstå, hvad underviser meddeler de måske 45 minutter, forelæsningen varer. Med begrebet interaktion handler det om, at den studerende (adressat) kan spørge ind til det, som underviser er i gang med at formidle. Det kræver på den ene side, at den studerende retter sin opmærksomhed mod den af underviseren meddelte information og derefter vælger sin forståelse af den meddelte information. Det vi kan kalde en kommunikativ forståelse, som naturligvis er den studerendes egenforståelse, og ikke nødvendigvis den forståelse af den meddelte information, som underviseren har tænkt sig. Den studerende (adressat) vælger forståelse ud fra sine forudsætninger. Først ved den studerendes (adressats) valg af efterfølgende meddelelse (når det er en mulighed) kan der tilskrives en forståelsesselektion (3. selektion). Denne pointe er væsentlig at medtænke i interaktionssystemer, der er netmedierede, hvor antallet af kommunikative tilslutningsmuligheder er reduceret (for udfoldelse, se Mathiasen, 2002).

Hvis den studerende (adressat) vælger forståelse og tilmed vælger at deltage i interaktionen, dvs. fortsætte kommunikationen med sin del af en ny kommunikationsenhed (valg af information og meddelelsesform), så er adressat blevet den meddelende af information. Derved bliver underviser til adressat, og den der nu skal vælge forståelse af det, som den studerende har valgt at meddele. Denne vekslen mellem rollerne som meddeler af information og adressat vil fortsætte, så længe underviser og studerende kan etablere synteserne af de tre selektioner (Luhmann, 1992). Den meddelende kan bruge sprog i bredeste betydning, dvs. bl.a. kropssprog, gestik, intonation, pausering, mimik, verbalt sprog, synkrone/asynkrone tekster, animationer, simuleringer m.m. Den meddelte information (de to første selektioner) kan iagttages, mens den tredje selektion, valg af forståelse ikke kan iagttages, fordi det handler om adressats bevidsthedsaktiviteter. Da vi som udgangspunkt er black box for hinanden (Luhmann, 1992), er kommunikation dybest set det eneste, vi har at gribe til, når en underviser gerne vil konstruere viden om, hvad den studerende har lært. Når en studerende i et forskningsinterview giver udtryk for, at videoforelæsninger ikke er undervisning (Mathiasen, 2010), har han ret set i den præsenterede kommunikationsteoretiske optik, hvis videoformatet bruges som formidlingsformat og ikke har indlejret mulighed for interaktion mellem underviser og studerende eller mellem de studerende. Med det præsenterede kommunikationsbegreb er konsekvensen at blot det at meddele noget, ikke i sig selv er kommunikation og dermed ikke undervisning, da undervisning defineres som den særlige og specialerede form for kommunikation, der intenderer forandring blandt de, der retter deres opmærksomhed med kommunikationen, og undervisning er interaktionssystemer (Luhmann, 2006).

Undervisning og læring, forstået som videnskonstruktion (i bredeste betydning), er gensidige afhængige systemer, hvor undervisning lidt firkantet formuleret kan ses som et interaktionssystem, der i sig har muligheden for kommunikativt at "forstyrre". Fx kan underviser med sine valg af information og meddelelsesform "forstyrre" den studerendes forståelse af et fænomen, som kan give anledning til, at den studerende reflekterer, reviderer og konstruerer ny viden, hvis underviser stiller sig kommunikativt til rådighed, $\mathrm{fx}$ ved at deltage i gruppediskussioner, diverse netfora, i paneldiskussioner, feedbackfora osv. I sådanne interaktionskontekster gælder det selvfølgelig, at alle deltagende kan lade sig "forstyrre" og dermed revidere og skabe nye videnskonstruktioner. 


\section{Videoformater set som læringsressource - kategorier og en kommunikationsoptik}

Videoformatet, i sine mange former, er en potentiel læringsressource, der har tiltrukket sig en særlig bevågenhed i den didaktiske diskussion nationalt og internationalt (Bates, 2019). Det betyder ikke, at der er udviklet en konsensus om hverken en kategorisering af videoformaterne eller den didaktiske tilgang til at bruge videoformater. Dét at bruge video er ikke nødvendigvis et udtryk for didaktisk nytænkning. Eksempelvis kan podcastede forelæsninger med en fortløbende slidepræsentation i den ene skærmside ("talking head") ikke i sig selv betragtes som et udtryk for nytænkning af undervisningen, set ud fra den præsenterede begrebsramme. En sådan anvendelse af et videoformat kan mere ses som en "cementering" af traditionelle tilgange til begrebet undervisning på universiteterne, der har været gængs nationalt og globalt gennem flere hundrede år.

Der kan overordnet skelnes mellem videoer, der primært tilbyder formidling og videoer, der tilbyder elementer af interaktivitet. I en produktionsoptik kan der overordnet skelnes mellem professionelt udførte videoproduktioner og "dogme"-koncepter udført af studerende og undervisere uden professionelt udstyr. Mellem disse yderpositioner befinder der sig en vifte af videoformater, og disse formater bruges med variation $\mathrm{i}$ forskellige undervisningskontekster med diverse tilknyttede undervisningsaktiviteter.

\section{Interaktive videoer}

Begrebet interaktive videoer tilbyder forskellige former for interaktivitet set $\mathrm{i}$ et kommunikationsperspektiv. Eksempelvis vil et interaktivt videoformat, som tilbyder filmet forelæsning med løbende multiple choice test med efterfølgende testresultat, her blive betragtet som en simpel form for interaktivitet. Der er i princippet tale om formidling, og hvis den studerende vælger at tage testen, kan den studerende få en "programmeret" feedback. Der er derfor tale om typer af interaktive videoer, der kan betegnes som en kommunikativ simpel interaktionsressource. Denne form for videoer kan produktudvikles $\mathrm{fx}$ ved at testresultater afgør vejen videre frem (eller tilbage) i den konkrete video. Sådanne adaptive tilgange til videoen som læringsressource er stadig en simpel form for kommunikation, idet det er videodesignerne, der har tilrettelagt ("programmet") interaktionerne. I en anden ende af spekteret af interaktive videoformer er det fx muligt med synkron interaktion under videoforløbet. Her er der tale om ikke-programmeret interaktion.

\section{Videoer anvendt før, under og efter undervisningen}

Anvendelse af videoformater i undervisningen (campusbaseret og netmedieret) kan også betragtes ud fra en undervisningsrelateret tidsdimension. Den refererede litteratur giver flere eksempler på brug af video som forberedelse til undervisningen, i selve undervisningen og efterbehandling af undervisningen.

Når video tilbydes før undervisning, er formålet ofte at give et fagligt fundament for deltagelse i den efterfølgende undervisning/undervisningsaktiviteter. Disse videoer kan endvidere have som formål at vække interesse, motivation og engagement hos den studerende. Sådanne videoer kan også være et tilbud om at teste sig selv før undervisningen, med det formål, at den studerende erfarer, om der skal mere forberedelse til for at få det optimale ud af undervisningen. Når det drejer sig om brug af videoer, der indgår i undervisningen, kan der være flere formater i spil, blandt andet instruktions- og demonstrationsvideoer, med det formål at understøtte laboratorieundervisning og forskellige former for laboratorieaktiviteter. Anvendelse af videoformater efter undervisningen eller efter undervisningsaktiviteter kan som formål have at give den studerende mulighed for at teste sig selv og dermed give den studerende mulighed for at handle i forhold til testresultaterne. Studenterproducerede 
videoformater som fx feltvideoer og formidlingsvideoer samt store mængder af open access netmedierede videoer tilbyder mange muligheder for den studerende til selv at vælge ressourcer, hvilket gælder både før, i og efter den konkrete undervisning.

\section{Video som feedbackformat}

Som feedback-ressource kan videoformatet tilbyde både lyd, billede og video, eksempelvis i form af screencasts. Sådanne videoer indeholder formidling af feedback-information produceret af feedback'eren med den studerendes producerede tekst på skærmen og med mulighed for både feedback'ers "voice over" og samtidige løbende markering i den studerendes tekst (synkront). Denne form for dynamisk feedback kan give den studerende indtryk af en synkronisitet og interaktion, selvom den studerende tilgår feedbackmediet, efter det er produceret. Formatet giver studerende og undervisere mulighed for efterfølgende at deltage i interaktioner om den givne feedback, hvor de anvendte videoer kan danne et frugtbart grundlag for mundtlig feedback. Et projekt med fokus på underviseres muligheder for at kvalitetsudvikle feedback på laboratorierapporter viste, at både undervisere og studerende pointerede, at det ville være en kvalitetsforbedring, hvis undervisernes screencast-feedback blev fulgt op af mundtlig on-campus feedback sammen med de studerende (Mathiasen, 2018). I dette eksempel er tiden i fokus i den forstand, at brugen af screencast inviterer til yderligere interaktion og dermed til et øget tidsforbrug.

\section{Konkluderende perspektivering}

Videoformater bliver brugt i stadig større omfang på universiteterne både i et nationalt og et globalt perspektiv og disse formater er til stadighed blevet mere funderet i pædagogisk og didaktisk forskning. Både undervisningspraksis og forskning har bidraget til en løbende produktudvikling, og med et voksende fokus på de studerendes mulighed for at lære sig det, der er intenderet i forbindelse med brug af de konkrete læringsressourcer i konkrete undrvisningskontekster.

Videoer kan, i den præsenterede kommunikationsteoretiske optik og med inspiration fra litteraturen, ses som en læringsressource, der har potentiale til at initiere og understøtte interaktionsaktiviteter. En "forelæsningsvideo" kan sjældent stå alene, men skal tænkes som en ressource, som de studerende kan bruge til de konkrete undervisningsaktiviteter, der er rammesat på de enkelte kurser. De studerende skal have mulighed for at afprøve deres forståelse af ved at deltage i interaktioner med deres medstuderende og undervisere, hvor videoens formidlede informationer bliver aktualiseret og diskuteret. Videoformaterne har lidt groft sagt udviklet sig fra et fokus på formidling til et fokus på brug videoformater som en læringsressource, der skal tænkes ind i en pædagogisk og didaktisk kontekst. Udviklingen af videoformater har et stadig større fokus på personalisering og synkron interaktion, hvilket inviterer til forsat udvikling af formater, der både inkludere en individuel og en social dimension i deres funktionalitet.

Med udgangspunkt i den refererede forskning og den anvendte kommunikationsoptik, er det både vigtigt og afgørende, set i et didaktisk perspektiv, hvilke formater der vælges i de konkrete undervisningskontekster. De forskellige videoformater har forskellige funktioner og formål, det gælder både de studerendes og undervisernes "håndholdte" videoproduktioner, og de professionelt producerede produktioner samt de variationer, hvor studerende, undervisere, forskere og professionelle deltager i videoproduktionerne. Formål med undervisningen skal være rammesættende for valg af videoformater, hvilket inkluderer valg af kommunikations- og læringsoptik for den flerhed af didaktiske beslutninger, der skal tages i den konkrete anvendelseskontekst.

Hermed en opfordring til fortsat didaktisk udvikling og forskning, med sigte på at udvikle undervisning, hvor videoformater, set som læringsressourcer, anvendes med intentionen om at give den studerende 
mulighed for at deltage i campus-baserede og netmedierede interaktioner med undervisere og medstuderende. Med fokus på udvikling af videoformater opfordres til fortsat at tænke studerende, underviser, forskere og professionelle videoproducenter som aktører i praksis, når det handler om udvikling af videoproduktioner.

\section{Referencer}

Bates, T. (2019). Is the current use of video a step backwards in online learning? | Tony Bates. Retrieved from: https://www.tonybates.ca/2019/03/08/is-the-current-use-of-video-a-step-backwards-in-online-learning/

Baturay, M. H. (2015). An Overview of the World of MOOCs in Procedia - Social and Behavioral Sciences. Elsevier, Volume 174. https://doi.org/10.1016/j.sbspro.2015.01.685

Bregnhøj, H., Neutzsky-Wulff, C., Ehrensvärd, M. G., Rosthøj, S., Sichlau Bruun, C., Harker-Schuch, I. E., Lysák, M., \& Jae Chuang, V. (2016). The Use of Videos in Teaching - Some Experiences From the University of Copenhagen. Tidsskriftet Læring Og Medier (LOM), 9(16). https://doi.org/10.7146/lom.vgi16.24416

Buus, L., Godsk, M., \& Hachmann, R. (2018). Learning design - pædagogiske og didaktiske modeller for undervisningsudvikling, kvalitetssikring og effektivisering på de videregående uddannelser. Tidsskriftet Læring Og Medier (LOM), 9(15). https://doi.org/10.7146/lom.vgi15.104445

Caswell, T., Henson, S., Jensen, M., \& Wiley, D. (2008). Open Content and Open Educational Resources: Enabling universal education. The International Review of Research in Open and Distributed Learning, 9(1). https://doi.org/10.19173/irrodl.v9i1.469

Cuban, L. (1986). Teachers and Machines. The classroom of technology since 1920. New York: Teacher College press

Cuban, L. (2002). Oversold \& underused. UK: Harvard University Press

Danielsen, O., Dirckinck-Holmfeld, L., Sørensen, B.H., Nielsen J. \& Fibiger, B. (Red.) (1997) Læring og Multimedier. Aalborg: Aalborg Universitetsforlag

Danielsen, O., Nielsen, J. \& Sørensen, B.H. (eds.) (2002). Learning and Narrativity in Digital Media. Kbh.: Samfundslitteratur

Elstad, E. (red) (2016). Digital Expectations and Experiences in Education. Rotterdam: Sense Publisher

Fibiger, B., Nielsen, J., Dirckinck-Holmfeld, L., Sørensen, B.H. \& Danielsen, O. (Red.)(2001). Design af Multimedier. Aalborg: Aalborg Universitetsforlag

Fog-Petersen, C. \& Arnfred, S. (2014). Bedside Ipad videooptagelser som læringsredskab i klinisk psykiatri. Tidsskriftet Læring Og Medier (LOM), 7(12). https://doi.org/10.7146/lom.v7i12.17275

Godsk, M., \& Dalsgaard, C. (2009). Implementering af lyd, video og interaktive medier i undervisningen. Tidsskriftet Læring Og Medier (LOM), 2(2). https://doi.org/10.7146/lom.v2i2.3959

Godsk, M., \& Hansen, J. (2016). Learning design som systematisk alternativ til one-hit wonders - implementering af educational it i de våde fag på Aarhus Universitet. Tidsskriftet Læring Og Medier (LOM), 9(15). https://doi.org/10.7146/lom.vgi15.23127

Hansen, P., Henriksen, P. \& Larsen, K. (1995). Udvikling af Multimedier.Kbh.: Teknisk forlag

Hansen, K., \& Jensen, K. (2016). Studenterproduceret video til eksamen. Tidsskriftet Læring Og Medier (LOM), 9(15). https://doi.org/10.7146/lom.vgi15.23118

Heilesen, S. (2009). Om erfaringer med podcasts i universiteternes undervisning. Tidsskriftet Læring Og Medier (LOM), 2(2). https://doi.org/10.7146/lom.v2i2.3909

Huber, E. \& Werner, A. (2016). A review of the literature on flipping the STEM classroom: Preliminary findings. In S. Barker, S. Dawson, A. Pardo, \&C. Colvin (Eds.), Show Me The Learning. Proceedings ASCILITE 2016 Adelaide(pp. 267-274)

Langset, I. D., Jacobsen, D.Y. \& Haugsbakken, H. (2018). Digital professional development : Towards a collaborative learning approach for taking higher education into the digitalized age. In Nordic Journal of Digital Literacy, 13(1)

Lauridsen, H., Nørgård, C., \& Toftegaard, R. (2016). Læring med videoteknologi - peer feedback og videosupervision. Tidsskriftet Læring Og Medier (LOM), 9(16). https://doi.org/10.7146/lom.vgi16.24373

Laurillard, D. (2012). Teaching as a Design Science. Building Pedagogical Patterns for learning and Trchnology. New York: Routledge

Løkkegaard, S., \& Ryberg, T. (2013). Potentialer og problematikker ved livestreaming og fastholdelse af undervisning. Tidsskriftet Læring Og Medier (LOM), 6(11). https://doi.org/10.7146/lom.v6i11.8812

Luhmann, N. (1992): What is Communication i Forum, Communication Theory, 2:3, p. 251-258

Luhmann, N. (2000): Sociale systemer. Kbh.: Reitzels forlag 
Luhmann, N. (2006): Samfundets uddannelsessystem. Kbh.: Reitzels forlag

Mathiasen, H. (2002): Personlige bærbare computere i undervisningen. Kbh.: DPU's forlag

Mathiasen, H. (2004). Expectations of Technology: When the Intensive Application of IT in Teaching Becomes a Possibility. In Journal of Research on Technology in Education, 36(3), 273-295.

Mathiasen, H. (2008). Is There a Nexus between Learning and Teaching? : Communication as a Facilitator of Students' Knowledge Construction. In C. Holtham, \& C. Nygaard (ed.), Understanding Learning-Centred Higher Education. Frederiksberg: Copenhagen Business School Press.

Mathiasen, H. \& Schrum, L. (2008). Web 2.0 and social software: Challenges and Complexity of Communication in Education. In Lecture Notes in Computer Science: HCI and Usability for Education and Work. Germany: Berlin Heidelberg: Springer.

Mathiasen, H. \& Schrum, L. (2010). New Technologies, Learning Systems and Communication: Reducing Complexity in the Educational System. I M. S. Khine, \& I. M. Saleh (ed.), New Science of Learning: Cognition, Computers and Collaboration in Education. USA: Springer Publishing Company

Mathiasen, H. (2010). Brug af podcast i undervisningen: muligheder og begrænsninger. Læring og Medier, (5).

Mathiasen, H. (2015). Digital Voting Systems and Communication in Classroom Lectures : an empirical study based around physics teaching at bachelor level at two Danish universities in Journal of Interactive Media in Education, Vol. 2015

Mathiasen, H. (2018). Digital media as feedback tools. Teachers' and students' experiences and reflections - focus on communication. Paper, Blended Conference 2018, LERU "Digital Higher Education Summit"

McKerlich, R., Ives, C. \& McGreal, R. (2013). Measuring use and creation of open educational resources in higher education. The International Review of Research in Open and Distributed Learning, 14(4),. Athabasca University Press. Retrieved February 14, 2019 from https://www.learntechlib.org/p/148191/.

Mor, Y., Mellar, H. Warburton, S. \& Winters, N. (eds). (2014). Practical Design Patterns for Teahing and Learning with Technology. Rotterdam: Sense Publisher

Neutzsky-Wulff, A. C. (2009). Nærhed i fjernundervisning - om brugen af audio og video i sprogundervisning. Tidsskriftet Læring Og Medier (LOM), 2(2). https://doi.org/10.7146/lom.v2i2.3915

Nordic University Health Hub | OER Commons (2019). Retrieved from https://www.oercommons.org/hubs/nordic universities

Rattleff, P., \& Holm, L. (2009). Barrierer for ibrugtagning af videooptaget universitetsundervisning. Tidsskriftet Læring Og Medier (LOM), 2(2). https://doi.org/10.7146/lom.v2i2.3911

Reutemann, J. \& Rubner, A. (2018). Manifesto Videos in Higher Education. https://www.academia.edu/36831393/Manifesto Videos in Higher Education?auto=download

Sims, R. (2008). Rethinking (e)learning: A manifesto for connected generations Distance Education, 29(2), 153164.

Wang, Q., Nieveen, N., \& Akker, J. v.d. (2007). Designing a computer support system for multimedia curriculum development in Shanghai. Educational Technology Research and Development, 55, 275-295

Zawacki- Richter, O., Bozkurt, A., Alturki, U. Aldraiweesh, A (2018). What Research Says About MOOCs -An Explorative Content Analysis in InternationalReview of Research in Open andDistributed Learning.19 (1) 


\section{Forfatter}

\section{Helle Mathiasen}

Professor, ph.d.

Institut for Naturfagenes Didaktik,

Københavns Universitet 